\title{
Technical Progress on Environmental-Friendly, High-Performance Water-Based Drilling Fluids
}

\author{
Junyi Liu*, Gongrang Li, Ye Xia \\ Drilling Technology Research Institute of Shengli Petroleum Engineering Corporation Limited, SINOPEC, Dongying 257100, \\ China
}

Corresponding Author Email: liujy9268.oss1@sinopec.com

https://doi.org/10.18280/eesrj.070305

Received: 20 April 2020

Accepted: 29 June 2020

\section{Keywords:}

water-based drilling fluids, environmentalfriendly, high-performance, research progress, development trend

\begin{abstract}
Oil and gas explorers around the world have gradually shifted their attention to complicated geological reservoirs, such as deep or ultra-deep, unconventional, and deepwater reservoirs. Against this trend, drilling fluids must meet stricter requirements, making the drilling in such reservoirs safe, fast, efficient, and environmental-friendly. Recent years has seen the emergence of environmental-friendly, high-performance waterbased drilling fluids, which boast comparable performance as oil-based drilling fluids. Some high-performance water-based drilling fluids have been developed specifically as per the technical requirements of drilling into complicated geological reservoirs. However, China lags far behind in the development of environmental-friendly, highperformance water-based drilling fluids. This paper summarizes the latest technical progress on environmental-friendly, high-performance water-based drilling fluids at home and abroad from three aspects, namely, environmental-friendly, high-performance water-based drilling fluids, environmental-friendly drilling fluid additives, and environmental evaluation methods for drilling fluids. Moreover, the development trend of the technology of environmental-friendly, high-performance water-based drilling fluids was discussed, providing a reference for further research into environmentalfriendly, high-performance water-based drilling fluids.
\end{abstract}

\section{INTRODUCTION}

Drilling fluid technology is an important part of the oil and gas drilling engineering, which plays a key role in well construction. The research and development of highperformance drilling fluids has always been the research focus and hotspot in the drilling engineering industry. With the increasing difficulty of oil and gas exploration and the constant pursuit of economic and environmental benefits, "safe, fast, quality, environmental friendly and efficient" have become higher goals for the development of drilling engineering technology, which will inevitably put forward more comprehensive and higher technical requirements for drilling fluids [1-3].

The performance of polymer drilling fluids, poly-sulfonate drilling fluids, and other conventional water-based drilling fluids could not meet the drilling requirements of complex structured wells, and their environmental properties and high temperature resistance need to be further improved comprehensively. The oil-based drilling fluids have the advantages of strong inhibition, excellent lubricity and hightemperature stability, and have become an important technical measure for complex structured wells drilling $[4,5]$. However, with the continuous improvement of environmental laws and regulations and the environmental protection requirements, the environmental protection situation of drilling engineering is becoming more serious. Especially in environmentally sensitive and ecologically fragile areas, drilling fluids have become one of the major pollution sources of the drilling engineering, the large amount of waste drilling fluids and oilcontaining cuttings cannot be discharged directly, and special processes are needed for decontamination treatment. The related process technology is complicated, the equipment investment is large, and the treatment cost is high, all of which have greatly limited the large-scale application of oil-based drilling fluids. To this end, researching and developing a kind of environmental friendly high-performance water-based drilling fluid which is simple to prepare, easy to maintain, cost-acceptable, has the advantages of oil-based drilling fluid and could overcome the shortcomings of traditional drilling fluids such as interfering with geological logging, is conductive to significantly reduce complex drilling accidents, improve the comprehensive benefits of oil and gas drilling development, and promote the exploration and development of complex oil and gas reservoirs [6-10].

International oilfield service companies have successively developed a series of environmentally-friendly highperformance water-based drilling fluids with similar performance of the oil-based drilling fluids, and proposed a "customized" design concept for high-performance waterbased drilling fluids. At present, great progress has been made in environmental friendly water-based drilling fluids, and has developed polyamine water-based drilling fluids in China, shale gas "water-substitute-oil" high-performance waterbased drilling fluid, etc. However, in terms of high temperature resistance and environmental protection performance of drilling fluids, there is still a big gap compared with the mature patent technology. Researching and 
developing environmental friendly high-performance waterbased drilling fluids and key additives with independent intellectual property rights is one of the important issues in the current drilling fluid technology. Therefore, this paper reviews the new research progress on environmental friendly highperformance drilling fluid technology at home and abroad from three aspects: environmental friendly high-performance water-based drilling fluids, environmental friendly highperformance additives, and drilling fluid environmental protection performance evaluation method, it looks into the development trend, and provides a reference for the research and development of environmental friendly high-performance drilling fluids $[11,12]$.

\section{RESEARCH ON ENVIRONMENTAL FRIENDLY HIGH-PERFORMANCE WATER-BASED DRILLING FLUIDS}

\subsection{Foreign research progress}

In recent years, international oilfield service companies have carried out a series of research on environmentallyfriendly high-performance water-based drilling fluids with the goals of reducing drilling fluid toxicity, reducing drilling fluid pollution, and improving the high-temperature resistance of drilling fluid additives. M-I SWACO focused on formulation optimization of water-based drilling fluids to achieve the goal of oil-based-imitated drilling fluids. The ULTRADRILL safe and high-performance environmental friendly water-based drilling fluid system, Hydra-Glyde high-performance waterbased drilling fluid system were successively developed, which proposed the "customized" design concept for highperformance water-based drilling fluids $[13,14]$. Among them, the ULTRADRILL safe and environmentally-friendly highperformance water-based drilling fluid is composed of polyacrylamide (Ultra Cap), polyanionic cellulose (Poly Pac), polyamine inhibitor (Ultra Hib) and drilling speed synergist (Ultra Free), etc., the high-temperature resistance is up to $135^{\circ} \mathrm{C}$; the Hydra-Glyde high-performance water-based drilling fluid system consists of coating agent (Hydra Cap), biopolymer (Duo-Vis), ultra-low viscosity polyanionic cellulose (Poly Pac-UL), shale inhibitor (Hydra Hib), lubricant accelerating agent (Hydra Speed), etc., which maintains the advantages of the water-based drilling fluids such as good environmental adaptability and lower cost, as well as reduces the torque, achieves a drilling speed comparable to the oilbased drilling fluids, and meanwhile avoids drilling complexities such as wellbore instability, which provides a "fast, safe and flexible" drilling fluid technical solution for the drilling of complex structured wells. In addition, M-I SWACO explored new-type nano drilling fluid additives which inhibits fluid pressure penetration and filtrate intrusion by physically sealling the micro-pores, so as to improve wellbore stability of the drilling fluids in shale formations, and all nano-based additives meet strict HSE requirements and have good environmental performance.

Baker Hughes has combined the polyamine compound with the cloud point of the polymeric alcohol and the chemical plugging of aluminum, and the PERFORMAX highperformance water-based drilling fluid was developed, which utilizes the collective effect of nano-polymeric plugging agent (MAX-SHIELD), aluminum-based chemical plugging agent (MAX-PLEX), shale hydration inhibitor (MAX-GUARD), and polymer coating agent (NEW-DRILL) to plug shale pores and micro-fractures, and prevent fluid pressure penetration and filtrate intrusion. The PERFORMAX drilling fluid has the advantages of strong inhibition, high temperature stability, reservoir protection, and environmental friendly, and it can meet the discharge requirements of the Gulf of Mexico stipulated by the US Environmental Protection Agency [15]. EXXON has developed EHT non-toxic high-temperature brine or seawater-based drilling fluid for land and marine drilling [16]. The main additives are cellulose viscosfier and high-temperature synthetic polymers filtrate reducers. During field application, the maximum temperature at the bottom of the well reaches $215^{\circ} \mathrm{C}$ and the density reaches $1.86 \mathrm{~g} / \mathrm{cm}^{3}$. Based on the newly developed $175^{\circ} \mathrm{C}$ high temperature polymer viscosfier and rheological modifier, Halliburton successfully developed a $180^{\circ} \mathrm{C}$ high temperature bentonitefree drilling fluid, breaking through the technical bottleneck of high temperature stability of bentonite-free drilling fluid [17].

Table 1. Typical environmental friendly high performance water-based drilling fluids

\begin{tabular}{|c|c|c|c|c|}
\hline Drilling & luids & Characteristics & Additive & Applications \\
\hline \multirow[b]{2}{*}{ Schlumberger } & $\begin{array}{l}\text { HYDRA- } \\
\text { GLYDE }\end{array}$ & $\begin{array}{l}\text { Design flexibility, low additives usage, } \\
\text { excellent shale inhibition, high lubricity }\end{array}$ & $\begin{array}{l}\text { Hydra Speed, Hydra Hib, Hydra } \\
\text { Cap, Poly Pac-UL, Duo-Vis, etc }\end{array}$ & $\begin{array}{c}\text { Permian Basin shale gas } \\
\text { horizontal wells, Texas, US }\end{array}$ \\
\hline & $\begin{array}{l}\text { ULTRA- } \\
\text { DRILL }\end{array}$ & $\begin{array}{l}\text { Similar performance with OBM, stable } \\
\text { performance, low cost, micro-nano } \\
\text { sealing }\end{array}$ & $\begin{array}{l}\text { Ultra Hib, Ultra Cap, Poly Pac, } \\
\text { Ultra Free, etc }\end{array}$ & $\begin{array}{l}\text { Deep water, Ecologically } \\
\text { fragile areas, Shale drilling }\end{array}$ \\
\hline \multirow{2}{*}{$\begin{array}{l}\text { Baker } \\
\text { Hughes }\end{array}$} & $\begin{array}{l}\text { PERFOR- } \\
\text { MAX }\end{array}$ & $\begin{array}{l}\text { Wellbore stability, high penetration } \\
\text { rate, high lubricity }\end{array}$ & $\begin{array}{l}\text { MAX-SHIELD, MAX-PLEX, } \\
\text { MAX-GUARD, NEW-DRILL, } \\
\text { PENETREX, etc. }\end{array}$ & Deep water drilling \\
\hline & $\begin{array}{l}\text { TERRA- } \\
\text { MAX }\end{array}$ & $\begin{array}{l}\text { Excellent brittle and soft shale } \\
\text { inhibition, high penetration rate }\end{array}$ & $\begin{array}{c}\text { TERRA-COAT, MAX- } \\
\text { GUARD, TERRA-RATE, etc. }\end{array}$ & Brooks shale drilling, US \\
\hline \multirow{2}{*}{ Halliburton } & $\begin{array}{l}\text { SHALE- } \\
\text { DRIL }\end{array}$ & $\begin{array}{l}\text { Customized design, excellent shale } \\
\text { inhibition, high lubricity, low cost }\end{array}$ & $\begin{array}{l}\text { SHALE-DRIL-F, SHALE- } \\
\text { DRIL-H, SHALE-DRIL-B, } \\
\text { SHALE-DRIL-E }\end{array}$ & $\begin{array}{c}\text { Haynesville, Barnett, } \\
\text { Fayetteville, Eagle Ford } \\
\text { shale gas wells, Texas, US }\end{array}$ \\
\hline & $\begin{array}{l}\text { HYDRO- } \\
\text { GUARD }\end{array}$ & $\begin{array}{l}\text { Clay free, excellent shale inhibition, } \\
\text { stable performance in low and high } \\
\text { temperature, hydrate inhibition }\end{array}$ & $\begin{array}{c}10 \sim 24 \% \mathrm{NaCl}, \mathrm{CLAY} \text { SYNC II, } \\
\text { CLAY GRABBER }\end{array}$ & $\begin{array}{c}\text { Shallow or Deep water } \\
\text { drilling }\end{array}$ \\
\hline
\end{tabular}

\subsection{Domestic research progress}

In order to meet the performance requirements of drilling engineering, the types and quantities of additives in the drilling and completion fluids are inevitably increasing, which has caused greater damage to the fragile oilfield ecological environment. In recent years, a few drilling fluid environmental protection technologies have continuously 
developed, but most of them focus on the "end-of-pipe control", that is, the decontamination treatment of waste drilling fluids and the processing technology for oil-containing cuttings. But the related processing technology is complex, the equipment investment is large, and the processing cost is high. Therefore, since the 1990s, it has begun to pay attention to the research and development of environmental friendly drilling fluids, so as to control the pollution of drilling fluids from the sources, transform from "end-of-pipe control" to "sourcecontrol, process-control", and environmental friendly drilling fluids were successively developed, including polymeric alcohol drilling fluids, formate drilling fluids, silicate drilling fluids, alkyl glucoside drilling fluids, synthetic-based drilling fluids, etc., and their common features are low bio-toxicity, easy biodegradable, and little environmental impact. However, the above drilling fluids have not been popularized or widely applied due to high cost and unsatisfactory application effects. At the same time, in order to meet the drilling fluid performance requirements under complex formation conditions, the above drilling fluids are compounded with synthetic high molecular polymer or sulfonated additives in field application, which affects the overall environmental performance of the drilling fluids.

\subsubsection{Polymeric alcohol drilling fluids}

This fluid realizes the wellbore stabilizing function through the "cloud point effect" of polymeric alcohol, and its efficacy is closely related to the temperature at the bottom of the well, the type of polymeric alcohol, and the salinity of the drilling fluid, etc. In order to achieve the strong inhibition property of the drilling fluid, it is often combined with potassium chloride of a certain concentration, but high salinity polymeric alcohol drilling fluid could adversely pollute the environment.

\subsubsection{Formate drilling fluids}

This fluid has the characteristics of strong inhibition, good rheology and low solid phase content, and could significantly improve the thermal stability of natural polymers. It could enhance the high temperature resistance of xanthan gum to above $180^{\circ} \mathrm{C}$, but due to cost problems, it is often applied to the drilling of high temperature and high pressure well reservoir sections.

\subsubsection{Silicate drilling fluids}

The silicate drilling fluid, using silicate as the basic material, has the advantages of good inhibition, non-toxic, low cost, non-fluorescence, no influence on logging, etc., and it's recognized as economical drilling fluids that could adapt to complex formation requirements and meet the requirements of environmental protection and sustainable development. However, the silicate itself is limited by temperature and $\mathrm{pH}$ value, and the rheology and lubricity of the silicate drilling fluid are difficult to control in the field, which has limited its promotion and application.

\subsubsection{Methyl glucoside drilling fluids}

Alkyl glucoside drilling fluid is a newly developed waterbased drilling fluid that is non-toxic, biodegradable and could be used instead of the oil-based drilling fluids. In areas that are demanding in environmental protection, complex offshore formations, drilling of highly-deviated wells, extension wells and horizontal wells, it has a good application prospect.

\subsubsection{Synthetic based drilling fluids}

The synthetic drilling fluid is a kind of water-in-oil reverse emulsified dispersion drilling fluids which uses synthetic chemicals (such as esters, ethers and synthetic hydrocarbons) as base liquid to replace diesel oil and mineral oil as continuous phase. It has the advantages of non-toxic, biodegradable, pollution-free, favorable for wellbore stability and reservoir protection, but its cost is high, and the risk is high when drilling formations that are prone to fluid loss.

\section{RESEARCH ON ENVIRONMENTAL FRIENDLY ADDITIVES}

\subsection{Foreign research progress}

The research and development of non-toxic, biodegradable, environmental friendly drilling fluid additives is the key to the environmental friendly drilling fluids. In recent years, international oilfield service companies have successively developed new drilling fluid additives such as hightemperature resistant filtrate reducers, environmental friendly lubricants, etc., so as to meet the performance requirements of environmental friendly drilling fluids. In terms of hightemperature resistant filtrate reducers, the U.S. company NALCO has developed a copolymer of AMPS, AM and MBA. The copolymer has an AMPS monomer unit content of $57 \sim 61 \%$, which has good high temperature resistance and high valence metal ions resistance. It is mainly used as filtrate reducers and flow pattern stabilizers for drilling fluids under high temperature, high pressure and high salinity conditions. Germany company BASF has developed the Polydrill, a hightemperature sulfonated polymer filtrate reducer, its relative molecular weight is about $2 \times 10^{5}$, and its temperature resistance could reach above $200^{\circ} \mathrm{C}$, resistance to $\mathrm{KCl}$ and $\mathrm{NaCl}$ could reach saturation, and resistance to $\mathrm{Ca}^{2+}$ and $\mathrm{Mg}^{2+}$ could reach $4.5 \times 10^{4} \sim 10 \times 10^{4} \mu \mathrm{g} / \mathrm{g}$. The U.S. company ARCO has produced the Mil-Tem, a high-temperature resistant filtrate reducer, it is a copolymer of sulfonated styrene (SS) and maleic anhydride (MA) with a relative molecular weight between 1000 and 5000, and its resistance to high temperature is up to $200^{\circ} \mathrm{C}$. Baker Hughes has developed Pyro-Trol and Kem-Seal, two kinds of high-temperature filtrate reducers for drilling fluids, which are suitable for offshore drilling, and could be applied to $180^{\circ} \mathrm{C}$ high-temperature formations. PyroTrol is a copolymer of AMPS and AM, and Kem-Seal is a copolymer of AMPS and N-alkyl acrylamide (NAAM). In addition, international oilfield service companies also pay attention to the deep modification optimization of natural polymer materials such as starch and cellulose, but their hightemperature resistance is usually below $130^{\circ} \mathrm{C}$, and deep modification is still needed for further improvement of hightemperature resistance of natural polymer filtrate reducers. MI SWACO has developed a series of high-temperature resistant modified starch products such as Poly-Sal, Flo-Trol and DuoFlo, their supporting drilling fluid systems are mostly used in reservoir stratums of $100 \sim 130^{\circ} \mathrm{C}$, and when the well temperature is higher than $130^{\circ} \mathrm{C}$, the combination of hightemperature resistant modified starch and PAC-LV could obviously control the filtration loss within $10 \mathrm{~mL}$. At the same time, adding high-temperature resistant modified starch into the formate drilling fluids could significantly improve its hightemperature resistance, which not only effectively reduces the filtration loss, but also effectively cleans the wellbore and 
reduces the equivalent circulating density (ECD) of the drilling fluid. Another U.S. company Baroid has developed a starch dry-blend system that is biodegradable, and the produced water-based drilling fluid has non-Newtonian fluid properties, pseudoplasticity, and liquid filtration loss control properties at high temperatures.

In terms of environmental friendly lubricants, Baker Hughes uses fatty acids and polyethene polyamines to form fatty acid ammonium salts and fatty acid methyl esters combinations. The fatty acid ammonium salts have a strong adsorption effect on the surface of the drilling tools and rock mass, and they could form a stable oil film so as to enhance the ability to lubricating and stabilizing the wellbore. The U.S. company Eco Global Solutions has introduced the EGSTM DFL, a bonding lubricant for drilling fluids. The active components in DFL are associated with free ions in the wellbore to produce a smooth surface, which could effectively control the inherent eddy current in the flow interface. In the complex drilling projects such as large displacement wells angle-buildup well sections, it could effectively reduce friction and increase the rate of drilling. The high-performance lubricant XPL developed by U.S. company ProOne is equivalent to DFL of Eco Global Solutions, when using this product, the friction and torque are reduced throughout the system, effectiveness could be increased by $50 \%$ even where the curvature of the borehole is large.

\subsection{Domestic research progress}

At present, domestic environmental friendly water-based drilling fluid additives are mainly natural high molecular polymers, including starch, xanthan gum, cellulose, lignin, tannin, vegetable gum, etc., which are easy to be biodegraded and have good environmental performance. However, their high temperature resistance is generally around $130{ }^{\circ} \mathrm{C}$, and they are mainly used in the shallow-layer drilling. In terms of high-temperature resistant polymer filtrate reducers, they are mainly grafted and copolymerized with AMPS, AM, AA, NVP and other natural high molecular polymers. Various high-temperature resistant filtrate reducers were developed, and the highest high-temperature resistance can reach up to $180^{\circ} \mathrm{C}$, but they are all in the indoor research stage, and the environmental performance is greatly affected by synthetic monomers such as AMPS and AM. Shale inhibitors mainly include polyols, alkyl glucosides, organic salts, silicates, etc., these agents mainly inhibit the shale hydration expansion, and other compatible additives still need to be optimized; the high temperature viscosfiers are mainly high-temperature weak gel GEL and 80A-51, GEL takes biopolymers as the main raw materials, after surface activation, it was compounded with polymers and high-temperature protective agents, and 80A-51 is an acrylate copolymer, the high temperature resistance of the two additives were both lower than $150^{\circ} \mathrm{C}$; extreme pressure lubricants mainly include vegetable oil, polyether, ester, poly $\alpha$ - Olefins (PAO), etc. These lubricants are low in bio toxicity and biodegradable, but their thermal stability and oxidative stability still need further research and perfection.

In recent years, major international oilfield service companies have continued to pay attention to the deep modification and optimization of natural polymer materials such as starch and cellulose, and have successively developed a variety of environmental friendly drilling fluid additives to meet the performance requirements of environmental friendly drilling fluids. Domestic research on the drilling fluid additives have also made great progress, but most environmental friendly drilling fluid additives generally have the disadvantages of complicated synthesis process, high cost and single performance. At present, in the drilling process of complex high-temperature formations, artificial synthetic polymers and sulfonated treatment agents are still used. The contradiction between environmental protection and high temperature stability of drilling fluid additives has not been effectively solved yet. It is still necessary to use natural raw materials with abundant sources and low prices to carry out compounding or deep modification, simplify the production process, and develop new environmental friendly drilling fluid additives, so as to replace the conventional non-environmental friendly drilling fluid additives.

Drilling fluid filtrate reducers play an important role in maintaining the stability of drilling fluids. At present, the research on environmental friendly additives mainly focuses on the filtrate reducers, and the thermal stability of environmental friendly filtrate reducers directly affects the temperature resistance of environmental friendly drilling fluids. At present, as a non-toxic and easy-degradable environmentally-friendly drilling fluid filtrate reducer, the modified starch is widely used in drilling blocks in formations with low temperature, but its temperature resistance is usually below $130^{\circ} \mathrm{C}$, which has limited its application. However, due to the presence of a large number of reactive hydroxyl groups in the starch molecules, researcher usually adopt grafting copolymerization, cross-linking/etherification composite modification, cross-linking antioxidant, and other methods to improve the temperature resistant filtration loss effect of the modified starch. Among them, the composite ion-modified starch filtrate reducer CSJ was developed with corn starch as raw materials has better temperature resistance and filtration loss than conventional modified starch DFD, its salt resistance could reach saturation and its temperature resistance could reach up to $140^{\circ} \mathrm{C}$; another filtrate reducer FL-W20 has a temperature resistance up to $150^{\circ} \mathrm{C}$ by implanting non-toxic inorganic silicon elements into the starch molecules. Therefore, improving the temperature resistance of starch through deep modification is one of the important research directions of environmental friendly drilling fluid additives.

\section{ENVIRONMENTAL PERFORMANCE EVALUATION OF DRILLING FLUIDS}

Recently, a variety of environmental friendly drilling fluids and additives have been developed. However, a unified environmental performance standard and evaluation methods of drilling fluids has not yet been established, and there is a lack of effective evaluation data for environmentally friendly drilling fluid research. According to the classification of industrial waste, the waste drilling fluids are usually classified as industrial solid waste, and it differs according to the environmental protection system and technical level of each country in terms of storage, disposal and pollutant control standards. In China, the storage, disposal and management of waste drilling fluids should meet the requirements of the National Environmental Protection Law and the Water Pollution Prevention Law and the Solid Waste Pollution Prevention and Control Law. However, the current solid waste pollution control standards do not specifically mention the pollution control problems of waste drilling fluids. 
Table 2. Environmental performance evaluation indicators and recommended methods

\begin{tabular}{ccc}
\hline Indicators & Methods & Standard value \\
\hline $\mathrm{pH}$ & $\mathrm{CJ} / \mathrm{T}$ 99-1999 & $2 \sim 12.5$ \\
$\mathrm{~Pb} /(\mathrm{mg} / \mathrm{kg})$ & $\mathrm{GB} / \mathrm{T} 17140-1997$ & $\leq 1000$ \\
$\mathrm{Cd} /(\mathrm{mg} / \mathrm{kg})$ & $\mathrm{GB} / \mathrm{T} 17140-1997$ & $\leq 20$ \\
$\mathrm{Cr} /(\mathrm{mg} / \mathrm{kg})$ & $\mathrm{GB} / \mathrm{T} 17137-1997$ & $\leq 1000$ \\
$\mathrm{Hg} /(\mathrm{mg} / \mathrm{kg})$ & $\mathrm{GB} / \mathrm{T} 17136-1997$ & $\leq 15$ \\
$\mathrm{As} /(\mathrm{mg} / \mathrm{kg})$ & $\mathrm{GB} / \mathrm{T} 17134-1997$ & $\leq 75$ \\
$\mathrm{Petro} /(\mathrm{mg} / \mathrm{kg})$ & $\mathrm{GB} / \mathrm{T} 16488-1996$ & $\leq 3000$ \\
$\mathrm{EC} 50 /(\mathrm{mg} / \mathrm{L})$ & $\mathrm{GB} / \mathrm{T} 15440-1995$ & $>10000$ \\
$\mathrm{BOD}_{5} / \mathrm{COD} \mathrm{Cr} / \%$ & $\mathrm{HJ} / \mathrm{T} 86-2002$ & $\geq 10.0$ \\
\hline
\end{tabular}

Referring to the organic pollutant management requirements of OSPAR, OECD, ISO, and other foreign organizations, and combining with Regulations on Drilling Waste Management (Alberta Energy and Utilities Board Guidelines 50), Environmental quality standard for soils (GB15618-1995), Integrated wastewater discharge standard (GB8978-1996) and other relevant technical standards, representative drilling fluid environmental performance evaluation indicators and recommended evaluation methods (such as Table 2) are proposed preliminarily, including biological toxicity, biodegradability, heavy metal elements (cadmium, mercury, chrome, lead, arsenic), petroleum type, $\mathrm{pH}$, etc., all nine indicators of five categories, and the waste drilling fluids' toxicity, residual organic matter, accumulated heavy metals, hydrocarbon content and corrosive properties are evaluated respectively. It is worth noting that the test evaluation methods of the above evaluation indicators generally referred to the industrial standards of water quality or soils, and they are not really suitable for the environmental performance evaluation of drilling fluids, so they should further be investigated before promotion or application. According to the commonly used bio toxicity EC50 method, most drilling fluid additives are non-toxic or low-toxic, but it could not accurately reflect their environmental performance. This is because the original non-toxic or low-toxic single additive may produce toxic substances after compounding with other materials, and the determination of final toxicity should take drilling fluid as a whole for the bio toxicity testing.

Table 3 shows the classification standard of the biological toxicity level of drilling fluids. The biological toxicity (acute toxicity) evaluation methods include the mysida method, the luminescent bacteria method, the algae growth inhibition test, the flea activity inhibition test, etc. Among these methods, the mysida method and the luminescent bacteria method have been recognized by the US EPA and API. A large number of researches show that the luminescent bacteria method is more sensitive than the mysida method, and its detection accuracy is higher and the detection time is shorter and the cost is lower. In addition, it is recommended to use the ratio of $\mathrm{BOD}_{5} / \mathrm{COD}_{\mathrm{Cr}}$ to evaluate the biodegradability of drilling fluid additives. When $\mathrm{BOD}_{5} / \mathrm{COD}_{\mathrm{Cr}}<10 \%$, it is "hardly biodegradable", when $10 \% \leq \mathrm{BOD}_{5} / \mathrm{COD}_{\mathrm{Cr}}<25 \%$, it is "biodegradable", when $\mathrm{BOD}_{5} / \mathrm{COD}_{\mathrm{Cr}} \geq 25 \%$, it is "easily biodegradable".

Table 3. Bio toxicity classification standard

\begin{tabular}{cccc}
\hline Standard & EC50/(mg/L) & Standard & EC50/(mg/L) \\
\hline Extra & $<1$ & Low & $1000 \sim 10000$ \\
High & $1 \sim 100$ & None & $>10000$ \\
Middle & $100 \sim 1000$ & Emission & $>30000$ \\
\hline
\end{tabular}

\section{DEVELOPMENT TREND DISCUSSION}

With the continuous development of environmentallyfriendly drilling fluid technology, a number of environmentally-friendly high performance water-based drilling fluids imitated the oil-based drilling fluid performance have been developed at home and abroad, but their technical problems existing in the aspects of high-temperature resistance and comprehensive environmental performance still need further research and improvement. The development trend of environmentally friendly high-performance water-based drilling fluid technology is summarized as follows:

(1) In-depth study on the mechanism of improving the high temperature resistance of natural polymer materials, and on the basis of the advanced chemistry, biology and nanotechnology, natural raw materials that have rich sources and low price such as starch, cellulose, lignin, tannin extract and vegetable gum, etc., would be adopted for compounding or deep modification to develop low-cost, high-efficiency and environmentallyfriendly water-based drilling fluid additives, so as to provide material foundation for environmental friendly highperformance water-based drilling fluids.

(2) In the process of promotion and application of new additives and drilling fluids, the well drilling performance with environmentally friendly goals should be combined, and comprehensively evaluate the effects of new additives and drilling fluids should be conducted from aspects of drilling fluid stability, borehole stability, reservoir protection and environmental protection, so as to finally develop a series of environmentally-friendly water-based drilling fluids with similar performance of the oil-based drilling fluid performance, thereby obtaining the optimal comprehensive benefits.

(3) Establish a standard system for the environmental performance evaluation of drilling fluids from the two aspects of bio toxicity and biodegradability as soon as possible, to improve the accuracy and scientificity of the of environmental performance evaluation of drilling fluids and additives.

\section{ACKNOWLEDGMENTS}

The project is supported by National Science and Technology Major Project of China (2016ZX05040-005), China Postdoctoral Science Foundation (2017M612344), and Shandong province post-doctoral innovation projects (201703044)

\section{REFERENCES}

[1] Humood, M., Ghamary, M.H., Lan, P., Iaccino, L.L., Bao, X., Polycarpou, A.A. (2019). Influence of additives on the friction and wear reduction of oil-based drilling fluid. Wear, 422: 151-160. https://doi.org/10.1016/j.wear.2019.01.028

[2] Ali, J.A., Kalhury, A.M., Sabir, A.N., Ahmed, R.N., Ali, N.H., Abdullah, A.D. (2020). A state-of-the-art review of the application of nanotechnology in the oil and gas industry with a focus on drilling engineering. Journal of Petroleum Science and Engineering, 107118. https://doi.org/10.1016/j.petrol.2020.107118

[3] Li, X., Jiang, G., Shen, X., Li, G. (2020). Poly-l-arginine as a high-performance and biodegradable shale inhibitor in water-based drilling fluids for stabilizing wellbore. 
ACS Sustainable Chemistry \& Engineering, 8(4): 18991907. https://doi.org/10.1021/acssuschemeng.9b06220

[4] Mao, H., Yang, Y., Zhang, H., Zheng, J., Zhong, Y. (2020). Conceptual design and methodology for rheological control of water-based drilling fluids in ultrahigh temperature and ultra-high pressure drilling applications. Journal of Petroleum Science and Engineering, 188 : 106884 https://doi.org/10.1016/j.petrol.2019.106884

[5] Wang, H., Ge, Y., Shi, L. (2017). Technologies in deep and ultra-deep well drilling: present status, challenges and future trend in the 13th Five-Year Plan period (20162020). Natural Gas Industry B, 4(5): 319-326. https://doi.org/10.1016/j.ngib.2017.09.001

[6] Brady, M.E., Craster, B., Getliff, J.M., Reid, P.I. (1998). Highly inhibitive, low-salinity glycol water-base drilling fluid for shale drilling in environmentally sensitive locations. SPE International Conference on Health, Safety, and Environment in Oil and Gas Exploration and Production, Caracas, Venezuela. https://doi.org/10.2118/46618-MS

[7] Zha, X., Liao, X., Zhao, X., Liu, F., He, A.Q., Xiong, W.X. (2018). Turning waste drilling fluids into a new, sustainable soil resources for landscaping. Ecological Engineering, 121: 130-136. https://doi.org/10.1016/j.ecoleng.2017.06.026

[8] Mannekote, J.K., Kailas, S.V., Venkatesh, K., Kathyayini, N. (2018). Environmentally friendly functional fluids from renewable and sustainable sources-a review. Renewable and Sustainable Energy Reviews, 81: 1787-1801. https://doi.org/10.1016/j.rser.2017.05.274

[9] Akpan, E.U., Enyi, G.C., Nasr, G., Yahaya, A.A., Ahmadu, A.A., Saidu, B. (2019). Water-based drilling fluids for high-temperature applications and watersensitive and dispersible shale formations. Journal of Petroleum Science and Engineering, 175: 1028-1038. https://doi.org/10.1021/am2012799
[10] Hodder, M.H., Popplestone, A., Gwynne, P., Reynolds, D. (2005). High-performance, water-based drilling fluid helps achieve early oil with lower capital expenditure. SPE Offshore Europe Oil and Gas Exhibition and Conference, Aberdeen, United Kingdom. https://doi.org/10.2118/96798-MS

[11] Aftab, A., Ali, M., Sahito, M.F., Mohanty, U.S., Jha, N.K., Akhondzadeh, H., Azhar, M.R., Ismail, A.R., Keshavarz, A., Iglauer, S. (2020). Environmental Friendliness and high performance of multifunctional tween 80/ZnO-nanoparticles-added water-based drilling fluid: An experimental approach. ACS Sustainable Chemistry \& Engineering, 8(30): 11224-11243. https://doi.org/10.1021/acssuschemeng.0c02661

[12] Hossain, M.E., Wajheeuddin, M. (2016). The use of grass as an environmentally friendly additive in waterbased drilling fluids. Petroleum Science, 13(2): 292-303. https://doi.org/10.1007/s12182-016-0083-8

[13] Deville, J.P., Fritz, B., Jarrett, M. (2011). Development of water-based drilling fluids customized for shale reservoirs. SPE Drilling \& Completion, 26(4): 484-491. https://doi.org/10.2118/140868-PA

[14] Di, W., Yan, N., Ye, H. (2014). Overseas new progresses in nano drilling fluid technology for shale drilling. Drilling Fluid \& Completion Fluid, 31(6): 76-81.

[15] Bland, R.G., Waughman, R.R., Tomkins, P.G., Halliday, W.S. (2002). Water-base alternative to oil-base muds: do they actually exist? IADC/SPE Drilling Conference. https://doi.org/10.2523/74542-MS

[16] Nicora, L.F. (1998). Zirconium citrate: a new generation dispersant for environmentally friendly drilling fluids. IADC/SPE Asia Pacific Drilling Technology, Jakarta, Indonesia. https://doi.org/10.2118/47832-MS

[17] Tehrani, A., Young, S., Gerrard, D., Fernandez, J. (2009). Environmentally friendly water based fluid for HT/HP drilling. SPE International Symposium on Oilfield Chemistry, The Woodlands, Texas. https://doi.org/10.2118/121783-MS 